\title{
PERANAN ORANG TUA DALAM MENUMBUHKAN MINAT BELAJAR ANAK
}

\author{
Oleh : Pdt. Dr. Norce L. Saleky, M.Pd.K \\ Ketua Prodi Magister Pendidikan Agama Kristen (M.Pd)
}

\begin{abstract}
ABSTRAK
Minat belajar seorang anak bertumbuh di mulai dari orang tua dan keluarga. Karena orang tua dan keluarga adalah lingkungan yang pertama dalam mempengaruhi dan membiasakan anak-anak dalam hal belajar, karena segala pengetahuan dan kecerdasan intelektual manusia diperoleh pertama-tama dari orang tua dan keluarga. Dalam menumbuhkan minat belajar anak, orang tua adalah pendidik utama yang terus menerus dengan berbagi cara untuk merangsang anak agar anak tetap memiliki gairah dalam belajar. Hal itu dilakukan oleh orang tua dengan tetap mempertahankan motivasi belajar anak di mulai sejak anak lahir sampai masa Sekolah Menegah Atas dan sesudahnya. Namun dalam berbagai upaya yang dilakukan untuk membangkitkan minat belajar anak, orang tua sendiri haruslah memberikan contoh dan teladan dalam hal belajar sehingga bisa menjadi model yang bisa ditiru dan dilakukan oleh anak-anak. Beberapa upaya yang dilakukan dalam menumbuhkan minat belajar anak adalah; membangkitkan motivasi belajar dalam diri anak, menciptakan lingkungan fisik yang nyaman, menyediakan fasilitas belajar yang memadai, mendampingi anak dalam belajar, membangun kerjsama dengan guru di sekolah.
\end{abstract}

\section{Kata Kunci : Orang Tua, Minat, Belajar Anak}




\section{A. PENDAHULUAN}

Pada hakekatnya setiap keluarga ingin agar anak-anaknya bisa menjadi orang-orang yang sukses dan berhasil di masa yang akan datang. Banyak cara yang ditempuh oleh setiap orang tua dan keluarga untuk mencapai tujuannya itu, dimana salah satu cara yang ditempuh yaitu dengan mempertahankan motivasi belajar yang sudah dimiliki anak sejak lahir. Seperti di kutip oleh Gunarsa bahwa "orang tua dan keluarga adalah lingkungan yang pertama dalam mempengaruhi dan membiasakan anak-anak dalam hal belajar, karena segala pengetahuan dan kecerdasan intelektual manusia diperoleh pertama-tama dari orangtua dan keluarga. ${ }^{1}$

Dalam menumbuhkan minat belajar anak, orang tua adalah pendidik utama yang harus memotivasi dan merangsang belajar anak dengan berbagai cara yang dapat membangkitkan gairah belajar anak, dan lebih dari itu, orang tua sendiri haruslah memberikan contoh dan teladan dalam hal belajar sehingga bisa menjadi model yang bisa ditiru dan dilakukan oleh anak-anaknya, seperti dikemukakan oleh Tompson bahwa" anak-anak belajar dari apa yang mereka jalani dalam kehidupan mereka. Mereka menyerap pengetahuan tentang kejadian dunia, melalui apa yang mereka alami dan amati. Mereka lebih banyak mengikuti perilaku orang dewasa (dalam keluarga) dari pada belajar dari perkataan atau nasihat. Mereka lebih peka terhadap "kurikulum tersembunyi" di balik pengajaran yang di sampaikan lewat metode dan struktur yang memperkuat atau justru bertentangan dengan isi pengajaran."2

Namun, berdasarkan beberapa penelitian dan fakta yang ditemukan, bahwa belum ada pemahaman yang benar tentang pentingnya peranan orang tua dalam menumbuhkan minat belajar anak. Bahkan yang lebih ironisnya ada banyak orang tua yang belum menyadari fungsinya sebagai pendidik utama yang mendampingi anak anak pada saat belajar di rumah, malah masih beranggapan bahwa masalah mengajar dan mendidik itu adalah tanggung sekolah sehingga kenyataannya masih banyak yang melalaikan tugasnya sebagai

\footnotetext{
${ }^{1}$ Singgih D Gunarsa, Psikologi Untuk Keluarga (Jakarta: PT BPK Gunung Mulia, 1993), hlm. 1.

${ }^{2}$ J. Thompson, Keluarga Sebagai Pusat Pembentukan (Jakarta: PT BPK Gunung Mulia, 1999), hlm. 13.
} 
pendidik di rumah. Seharusnya setiap orang tua perlu menyadari bahwa peran mereka sebagai pendidik utama dalam keluarga adalah mendidik anak-anak mereka sebelum anak memasuki usia sekolah dan terus berlanjut sampai masa Sekolah Menengah Atas (SMA) dan sesudahnya. Tujuannya adalah supaya anak-anak itu berhasil dalam berbagai aspek dalam kehidupan masa depannya. Untuk itu di bawah ini penulis akan memberikan beberapa cara yang pelu dilakukan oleh setiap orang tua dalam menumbuhkan minat belajar anak.

\section{B. MEMBANGKITKAN MOTIVASI BELAJAR ANAK}

Motivasi berasal dari kata motif. Motif adalah daya dalam diri seseorang yang mendorongnya untuk melakukan sesuatu, atau keadaan seseorang atau organisme yang menyebabkan kesiapan untuk memulai serangkaian tingkah laku atau perbuatan. Jadi, motivasi adalah suatu proses untuk menggiatkan motif-motif menjadi perbuatan atau tingkah laku untuk memenuhi kebutuhan dan mencapai tujuan, atau keadaan dan kesiapan dalam diri individu yang mendorong tingkah lakunya untuk berbuat sesuatu dalam mencapai tujuan tertentu. ${ }^{3}$

Ada dua jenis motivasi, yaitu motivasi instrinsik dan ekstrinsik. Motivasi instrinsik adalah dorongan atau gairah yang timbul dalam diri anak. Misalnya anak ingin mendapat angka atau nilai yang baik, sebagai bukti "ia mampu berbuat atau ingin mendapat pujian dari orang tua atau teman sekelasnya atau lain sebagainya. Sedangkan motivasi ekstrinsik adalah faktor dari luar diri anak yang turut mendorong terjadinya gairah belajar. Seperti lingkungan fisik yang memberi kenyamanan, tekanan, kompetisi, fasilitas yang memadai dan lain sebagainya. $^{4}$

Menurut Sidjabat ada tiga alasan mengapa motivasi dikatakan penting atau perlu dalam diri seseorang karena: Pertama, karena watak dan sifat manusia membutuhkan dorongan, desakan serta rangsangan dari sesamanya. "besi menajamkan besi, manusia menajamkan sesamanya (Ams. 27:17). "Bertolong-tolonglah kamu menanggung

${ }^{3}$ Moh Uzer, Menjadi Guru Profesional (Bandung: Rosdakarya, 2002), hlm. 28.

${ }^{4}$ Sardiman A. M. Interaksi \& Motivasi Belajar (Jakarta: PT Raja Grafindo Persada, 2003), hlm. 87-88. 
bebanmu! Demikianlah kamu memenuhi hukum Kristus," tegas rasul Paulus (Gal. 6:2). Kedua, karena sifat dan perbuatan belajar itu sendiri sebagai proses dan upaya adanya, membutuhkan "suntikan-suntikan" dorongan, yang mana dorongan itu selalu terjadi melalui tantangan ataupun hukuman serta melalui pujian dan penghargaan. "Kita yang kuat wajib menanggung kelemahan orang yang tidak kuat dan jangan kita mencari kesenangan diri sendiri. Setiap orang di antara kita harus mencari kesenangan sesama kita demi kebaikannya, untuk membangunnya (Rm. 15:1-2). Dan ketiga, bahwa dalam mengajar anak, motivasi itu penting sehingga butuh orang tua dan guru selalu berusaha menggunakan metode yang relevan dengan kebutuhan anak sehingga mampu menarik minat belajar anak. ${ }^{5}$

\section{MENCIPTAKAN HUBUNGAN KELUARGA YANG HARMONIS}

Anak-anak dalam sebuah rumah selalu mendambakan kemesraan, kasih dan keamanan dari orang tuanya. Orang tua haruslah "menjadi rumah" bagi anak-anaknya. Dalam kitab Mazmur kerap kali dikatakan bahwa Tuhan adalah perlindungan bagi orang percaya, bahwa persekutuan dengan-Nya menjadi satu rumah bagi orang percaya. ${ }^{6}$ Muhbbin Syah juga mengatakan bahwa" suasana rumah atau keluarga sangat berpengaruh pada prestasi belajar anak. Misalnya sifat-sifat orang tua, pengelolaan keluarga yang salah atau keliru dan ketegangan keluarga, semuanya akan memberikan dampak yang baik atau buruk terhadap belajar dan hasil belajar anak. Contoh yang salah dalam mengelola keluarga seperti; kelalaian orang tua dalam memonitor kegiatan anak. Dalam hal ini, bukan saja anak tidak mau belajar melainkan juga cenderung berperilaku yang menyimpang. ${ }^{7}$

Jadi suasana rumah serta keharmonisan keluarga turut pula mempengaruhi gairah belajar seorang anak. Karena bila suasana rumah

${ }^{5}$ Sidjabat, Menjadi Guru Yang Profesional (Bandung: Yayasan Kalam Hidup, 2002), hlm. 110-111.

${ }^{6}$ Rex Jakson, Pernikahan Dan Rumah Tangga (Malang: Gandum Mas, 1978),

${ }^{7}$ Muhibbin Syah, Psikologi Belajar (Bandung: PT Raja Grafindo, 2005), hlm. 153. 
itu selalu gaduh, tegang atau ribut, maka akibatnya anak tidak dapat belajar dengan baik. Untuk itu, orang tua perlu memperhatikan bahkan berusaha menciptakan suasana rumah yang nyaman dan kondusif agar menolong anak dalam belajanya.

\section{MENYEDIAKAN FASILITAS BELAJAR YANG MEMADAI}

Fasilitas belajar tidak bisa dilepas pisahkan dengan masalah belajar. Bila fasilitas belajar di rumah dilengkapi, maka ada gairah atau semangat untuk anak mau belajar. Penyediaan fasilitas belajar bagi seorang anak di rumah sangatlah penting. Misalnya ada ruangan belajar yang di dalamnya ada meja, kursi atau peralatan-peralatan belajar, penerangan yang memadai, bahkan ruangan itu harus terpisah dengan ruangan-ruangan lain, agar anak tidak terganggu oleh anggota-anggota keluarga lainnya bila anak sedang belajar. "Fasilitas belajar ini tidak menitikberatkan pada fasilitas yang mewah atau mahal namun perlu pengaturan yang menitikberatkan kerapian, dan menimbulkan suasana tenang."

Penyediaan fasilitas belajar anak sangat penting seperti pendapat Alex Sobur bahwa" Sikap positif orang tua sangat besar pengaruhnya bagi kelancaran belajar anak. Namun kelancaran belajar itu pasti tidak dijamin kalau suasana keluarga tidak mendukung. Karena itu sebaiknya orang tua menyediakan tempat tertentu bagi anak untuk belajar. Di tempat itu anak dapat mengerjakan pekerjaan rumah (PR) tanpa ada gangguan. Bila keadaan memungkinkan bisa dibuatkan sebuah kamar khusus untuknya. Di rumah yang relatif kecilpun perlu diusahakan adanya tempat tertentu, misalnya di ruangan tidur anak. ini bukan syarat yang sepele, sebab lingkungan turut pula mempengaruhi sikap anak terhadap belajar." 9

\footnotetext{
${ }^{8}$ Gunarsa. Psikologi Praktis Anak Remaja \& Keluarga (Jakarta: BPK Gunung Mulia, 2001), hlm. 58.

${ }^{9}$ Alex Sobur, Butir-butir Mutiara Rumah Tangga (Yogyakarta: Kanesius, 1985), hlm. 160 .
} 


\section{E. MENDAMPINGI ANAK DALAM BELAJAR}

Lingkungan belajar sangat berperan besar sebagai sumber rangsangan untuk mempengaruhi perkembangan anak dan membentuk ciri karakter dari kepribadiannya sesuai dengan apa yang diharapkan. Pada dasarnya anak memiliki pembawaan atau kemampuan yang akan muncul dengan sendiri dan bisa pula dimunculkan dengan campur tangan dari lingkungan dalam bentuk pola asuh dan pendidikan formal maupun informal.

Pendidikan informal atau pendidikan di rumah sangatlah memberi pengaruh dalam memotivasi anak dalam belajar. Pengaruh orang tua dalam memotivasi belajar anak, akan berlanjut terus dalam setiap perkembangan anak dan terus berlanjut sampai habis masa Sekolah Menengah Atas (SMA). Keterlibatan orang tua secara antusias dalam memotivasi anak sangatlah penting. Hal memotivasi ini, kalau disadari maka akan dilakukan oleh setiap orang tua kepada anaknya dengan satu tujuan yaitu ingin anaknya berhasil dalam prestasi belajarnya di sekolah.

Keterlibatan orang tua dalam memotivasi anak bisa dilakukan dengan motivasi langsung maupun tidak langsung. Secara langsung misalnya: orang tua harus selalu membiasakan diri untuk mendampingi anaknya saat belajar sehingga membantu mengajarkan atau melatih anak. Kebiasaan mendampingi ini dilakukan secara berulang-ulang sampai anak bisa memahami atau mengerti. Selama mendampingi anak dan anak mulai berhasil mampu menyelesaikan suatu tugas dengan baik, maka orang tua harus memberikan pujian dengan kata-kata atau bisa juga memberikan penghargaan baginya yang membuat anak lebih bersemangat lagi dalam belajar.

Sedangkan motivasi tidak langsung misalnya; orang tua selalu melatih anak untuk mandiri sesuai sesuai dengan tahap perkembangan anak. Cara menumbuhkan kemandirian dengan membacakan ceritacerita dari Alkitab atau dari buku-buku tentang orang-orang yang berani pantang menyerah sampai berhasil dan lain sebagainya yang merangsang anak untuk mau melakukan sesuatu dengan usaha yang sungguh-sungguh. Selain itu, usaha lain dalam membina dorongan untuk berprestasi oleh orang tua tanpa sengaja atau tidak disadari oleh orang tua maupun anak-anak adalah anak meniru perilaku orang tua yang dijadikan model oleh anak. Misalnya sikap orang tua yang selalu berusaha dengan sabar, ulet, tabah gigih dan berorientasi pada 
kemajuan, maka anak akan meniru tokoh orang tuanya sebagai idolanya.

Ada tiga cara menurut Raymond Wlodkowsky yang perlu dilakukan oleh setiap orang tua dalam mendampingi anak terutama dalam hal belajar.

Pertama, Orang tua haruslah sebagai "sebuah model bagi anakanaknya." Hal ini perlu dilakukan bagi pembentukan belajar seumur hidup. Apa yang didengar dan yang dilihat dari sikap orang tua adalah yang paling kekal dari hal yang anak pelajari.

Kedua, Menjadikan anak sebagai pewaris kegunaan dasar-dasar belajar yang menggembirakan. Misalnya memberikan kepada anakanak (usia berapapun) sebuah dasar keteraturan, yang bisa dimulai dengan untuk manfaat menulis, orang tua selalu memasukan secarik kertas catatan di dalam kotak makan siang berupa ucapan terima kasih atau juga berupa pujian karena anak sudah melakukan suatu pekerjaan dengan baik.

Ketiga, Menjadikan anak sebagai mitra atau rekan kerja dalam aktivitas belajar dan dalam penerapan kemampuan-kemampuan akademis orangtua sendiri. Kata kuncinya adalah "kebersamaan." Misalnya membaca sesuatu yang menyenangkan bersama-sama, menulis puisi bersama-sama, memasak sesuatu yang lezat bersamasama dan lain sebagainya. Hal ini juga menjadi hal yang menyenangkan dan paling mengesankan, yang juga mempengaruhi motivasi belajar anak"10

\section{F. MEMBANGUN KERJASAMA DENGAN GURU DI SEKOLAH}

Membangun hubungan yang positif antara orang tua dan guru di sekolah merupakan salah satu kontribusi penting bagi prestasi anak di sekolah. Hubungan positif antara orang tua dan guru akan memberikan pengaruh yang sangat kuat dalam menciptakan suasana yang baik dalam mendukung belajar anak. Lewat hubungan seperti ini, orang tua bisa menerima penjelasan dari guru langsung tentang pekerjaan rumah (PR) anak, juga sangat membantu orang tua dalam memberikan

\footnotetext{
${ }^{10}$ Raymond Wlodkowsky, Hasrat Untuk Belajar (Jakarta: Cerdas Pustaka,
} 2004), hlm. 147-148. 
penghargaan kepada anak, bila anak dapat menyelesaikan pekerjaan rumahnya dengan baik. Dalam kerjasama seperti ini, dapat lebih memberikan pengaruh positif bagi motivasi belajar anak.

Terjalinnya hubungan yang baik antara orang tua dan guru sangat mempengaruhi keberhasilan belajar anak. Karena melalui hubungan seperti ini seorang guru akan lebih dekat lagi memahami dan mengenal anak dari latar belakang keluarga anak didik, bagaimana kondisi keluarga anak didik, ekonomi keluarga, kebiasaan belajar dan lain sebagainya. Sehingga bila ada masalah yang timbul, atau prestasi belajar anak didik menurun, maka dengan jelas guru akan membuat pertimbangan-pertimbangan berdasarkan latar belakang anak didik yang telah ia ketahui.

Ada beberapa cara yang perlu dilakukan oleh orang tua dan guru dalam membangun hubungan yang positif. Antara lain;

Pertama, "membangun komunikasi yang lancar." Tujuan membangun komunikasi, baik secara langsung maupun tidak langsung antara orang tua dan guru, akan lebih bermanfaat agar tidak saling mempersalahkan bila anak terkena masalah baik dalam kondisi kesehatan yang terganggu, atau dalam hal prestasi belajar yang menurun ataupun segala sesuatu menyangkut anak, orang tua dan guru bisa saling mengetahui secara langsung dan pasti. Bahkan dalam membangun hubungan komunikasi seperti ini, ada saling percaya antara orang tua dan guru di sekolah. Hal lain juga yang tidak kalah penting yaitu; dalam hal komunikasi sangatlah membantu. Misalnya; di pihak guru bila prestasi anak tiba-tiba menurun, atau anak tidak bergairah belajar, maka guru tidak segan-segan langsung mencari tahu penyebabnya dari orang tua. Ataupun sebaliknya melalui komunikasi dari pihak orang tua membantu guru dengan masukan tentang bakatbakat khusus yang ada pada anak, sehingga hal itu diperhatikan oleh guru dan lebih di rangsang lagi dalam belajar.

Kedua, "membangun kerjasama dalam memotivasi belajar anak," motivasi memegang peran penting dalam belajar seseorang. Tanpa motivasi seorang anak tidak dapat melakukan kegiatan belajar. Untuk itu perlu ada kerjasama dalam memperhatikan masalah motivasi belajar dalam diri anak dan berusaha semaksimal dalam mempertahankannya supaya anak tetap bergairah dalam belajar. Guru yang mengabaikan masalah motivasi akan mengalami kegagalan dalam melaksanakan tugas mengajar di kelas. Seperti dikutip oleh Djamarah bahwa"sangatlah penting bagi seorang guru untuk memilih suatu 
bentuk motivasi yang tepat untuk membangkitkan gairah belajar anak, salah satunya adalah dengan penggunaan metode yang bervariasi sehingga ada umpan balik. Hal ini akan menghasilkan komunikasi dua arah dan umpan balik ini akan berlangsung selama guru memberikan pelajaran di kelas." 11 Sedangkan bagi orang tua motivasi belajar akan dilakukan bila anak berada di rumah. Orang tua yang selalu ingin anaknya berhasil dalam prestasinya di sekolah, akan sungguh-sungguh menyisihkan waktunya untuk selalu bersama-sama mendampingi anak mereka. Saling kerjasama antara orang tua dan guru ini nampak dan terbukti jika orang tua juga bertanggung jawab dalam mendidik dan merangsang belajar anak di rumah, sehingga tidak menyerahkan tugas mengajar dan mendidik semata-mata kepada guru di sekolah.

Ketiga, "Orang tua dan guru bekerja sama dalam mencari jalan keluar bila anak mengalami masalah di sekolah." Orang tua dan guru adalah dua pihak yang mendorong berhasilnya anak di sekolah. Namun kedua pihak ini perlu juga ada kerja sama dalam mencari jalan keluar bila anak mengalami masalah di sekolah. Misalnya; ketika prestasi belajar anak menurun, karena mungkin anak belum bisa membaca dengan lancar sehingga tidak menangkap maksud dari pelajaran yang diterangkan maka orang tua dan guru perlu kerjasama dalam menyelesaikannya. Hal ini seperti di pertegas Yulia Gunarsa ia mengatakan bahwa "orang tua dan guru perlu kerja sama menangani masalah-msalah anak misalnya; anak yang suka bolos sekolah, anak yang tidak semangat dalam belajar, anak yang tidak naik kelas, berkelahi dan lain sebagainya perlu ada kerja sama dalam mencari jalan keluarnya."12

Seringkali kalau anak-anak gagal dan tidak naik kelas, orang tua mulai menyalahkan guru dengan beranggapan bahwa kurangnya usaha atau rendahnya prestasi anak-anak mereka di sekolah semata-mata karena ketidakmampuan atau ketidakpekaan guru dalam membimbing dan mengajar anak-anak mereka.

Sebaliknya dari guru bila ada anak yang tidak tahu membaca dan menulis, maka orang tua anak dipersalahkan karena mereka tidak membantu dalam mengajar anak dalam hal membaca, menulis dan

\footnotetext{
hlm. 182 .

${ }^{11}$ Syaiful Djamarah, Strategi Belajar Mengajar (Jakarta: Rineka Cipta, 2002),

${ }^{12}$ Yulia Singgih Gunarsa, Psikologi Anak Bermasalah (Jakarta: PT BPK Gunung Mulia, 1980), hlm. 15-20.
} 
berhitung. Hal lain lagi misalnya; bila anak suka bolos sekolah, guru di persalahkan karena tidak memperhatikan anak waktu keluar kelas, atau raport anak merah dan lain sebagainya. Dalam menanggapi situasi seperti ini, beda sikap antara orang tua yang satu dengan yang lain, ada yang merasa diam dan menunggu sampai ada rapat guru barulah diusulkan, namun ada pula orang tua yang tidak sabar mereka bisa salahpaham dengan guru dan terjadi ketidakharmonisan dalam hubungan mereka.

Namun bila orang tua dan guru yang sudah memiliki hubungan Komunikasi yang baik, maka bila ada masalah-masalah seperti di atas yang timbul di sekolah, maka orang tua dan guru akan tetap saling menghargai bahkan ada kerja sama dalam mencari penyebab dan jalan keluarnya. Jadi melalui kerja sama yang baik antara orang tua dan guru dalam memecahkan masalah anak di sekolah, maka akan merangsang atau membangkitkan semangat belajat anak kemabali sehingga ada gairah belajar dalam diri anak untuk terus maju dan berkembang.

\section{DAFTAR PUSTAKA}

A. M, Sardiman. Interaksi \& Motivasi Belajar Mengajar. Jakarta: PT Raja Grafindo Persada, 2003.

Djamarah, Syaiful. Strategi Belajar Mengajar. Jakarta: Rineka Cipta, 2002.

Gunarsa, Singgih. Psikologi Praktis Anak, Remaja Dan Keluarga. Jakarta: BPK Gunung Mulia, 2001.

Gunarsa, Singgih Yulia. Psikologi Anak Bermasalah. Jakarta: PT BPK Gunung Mulia, 1980.

Jackson, Rex. Pernikahan Dan Rumah Tangga. Malang: Gandum Mas, t.t.

Sidjabat, Samuel. Menjadi Guru Yang Profesional. Bandung: Yayasan Kalam Hidup. 2002.

Sobur, Alex. Butir-butir Mutiara Rumah Tangga. Yogyakarta: Kanisius, 1985. 
Syah, Muhibbin. Psikologi Belajar. Bandung: PT Raja Grafindo, 2005.

Thompson, J. Keluarga Sebagai Pusat Pembentukan. Jakarta: BPK Gunung Mulia, 1999.

Usman, Uzer. Menjadi Guru Profesional. Jakarta: PT Remaja Rosdakarya, 1992.

Wlodkowsky, Raymond. Hasrat Untuk Belajar. Jakarta: Cerdas Pustaka, 2004. 